\title{
THE MILITARY ASCENT INTO SPACE: FROM PLAYGROUND TO BATTLEGROUND-THE NEW UNCERTAIN GAME IN THE HEAVENS
}

\author{
Jackson Nyamuya Maogoto*
}

Control of space will be decided in the next century. If the Soviets control space, they can control earth, as in the past ... the nations that controlled the seas dominated the continents. ${ }^{2}[J o h n$ F Kennedy (1960)]

\begin{abstract}
Strategic vision is a rare phenomenon and exposes one to ridicule and skepticism. The early proponents of air and armored warfare had their detractors and skeptics before World War II validated their theories. Today, there is a new frontier, one that needs to be approached with vision and innovation if a nation is to prevail and survive independently and freely ... space, the new frontier. ${ }^{3}$ [Major Elek J Szkalak (1988)]

The mastery of outer space will be a requisite for military victory, with outer space becoming the new commanding heights for combat, ... lightning attacks and powerful first strikes will be more widely used in the future. ${ }^{4}$ [Captain Shen Zhongchang, Chinese People's Liberation Army (2001)]
\end{abstract}

\section{INTRODUCTION}

The United States and Soviet Union led the way in conquering space in the 1950s through a series of initiatives that included satellites, launch of spacecrafts and nuclear detonations. In October 1957, man conquered space with the launch of Sputnik I by the Soviet Union. In the same year, the United States successfully undertook nuclear detonations in space. ${ }^{5}$ Four years later, the Soviet Union launched the first manned spaceflight when it placed Yuri Gagarin into orbit. The United States followed suit in 1962. These activities effectively marked the start of a technological race between the United States and Soviet Union with each seeking dominance in space exploration marking the genesis of a space race which would soon metamorphose into an arms race. As the Cold War confrontation between the United States and the Soviet Union grew in intensity, the military utility space offered was not lost on the sea-faring nations. Research and

\footnotetext{
${ }^{*}$ LL.B. (Hons)(Moi), LL.M. (Hons)(Cantab), Ph.D. (Melb), GCertPPT (Ntle), Lecturer in International Law, School of Law, University of Newcastle (Australia).

${ }^{2}$ Quoted in Major Elek J. Szkalak, Military Implications of The Soviet Space Program (1988), available at http://www.globalsecurity.org/space/library/report/1988/SEJ.htm.

${ }^{3}$ Id.

${ }^{4}$ Leonard David, Pentagon Report: China's Space Warfare Tactics Aimed at U.S. Supremacy, 1 August 2003.

${ }^{5}$ A Tass news agency announcement of Aug. 27, 1957 which reported the successful test of the Soviet I.C.B.M. also included reference to "a series of explosions of nuclear and thermonuclear (hydrogen) weapons ... set off at great altitudes.” M.S. MCDougal, ET AL., LAW AND Public ORDER IN SPACE 389 n.7 (1963).
} 
development of state-of-the-art technology to capitalize on the utility of outer space got underway.

The international community was quick to generate rhetoric that states should use outer space for positive and peaceful purposes. A 1957 General Assembly resolution dealing with the topic of disarmament declared that "the sending of objects through outer space shall be exclusively for peaceful and scientific purposes." ${ }^{\circ}$ A year later, U.N. General Assembly Resolution 1348 recognized that the common aim of humankind was that outer space was to be used "for peaceful purposes only.", The United States and Soviet Union obliged with the United States adopting the view that:

\begin{abstract}
"[P]eaceful" in relation to outer space activities was interpreted...to mean "non-aggressive" rather than non-military...By contrast, the Soviet Union publicly took the view, despite its own military uses of space, that "peaceful" meant "non-military" and that in consequence all military activities in outer space were "non-peaceful" and possibly illegal. ${ }^{8}$
\end{abstract}

This divided sentiments by the two superpowers, the vanguard in the development of customary law on the matter, meant that despite general international sentiment championing nonmilitarization of space, the looming space arms race on the horizon had powerful "patrons".

The mastery of outer space as the basis of integrated battleground platforms is fast becoming a reality. As the two Gulf Wars and the Kosovo military campaign made clear, space assets are decisive in battle planning and execution. As the 21 st century unfolds, several decades after man's conquest of space, the increasing global reliance on space systems and an increasing militarization of space and its weaponization, its evolution into a distinct theatre of military

\footnotetext{
${ }^{6}$ G.A.Res. 1148 (XII), 12 U.N.GAOR Supp. No. 10-18 (1956-57).

${ }^{7}$ Ivan A. Vlasic, The Legal Aspects of Peaceful and Nonpeaceful Uses of Outer Space, in PEACEFUL AND NONPeACEful Uses of SpaCe: Problems of Definition for the PREVEnTION OF AN ARMs RaCe 39 (Bhupendra Jasani ed., 1991).

${ }^{8}$ Id at 40.
} 
operations is a matter of time. The worrying thing from the author's perspective is that when the reality of space warfare dawns, there will be a serious legal deficit in the absence of specific international norms restricting the use of means and methods of war in space. State practice as it currently exists offers no insights into how the law will be applied. Space law is patchy with regard to militarization and weaponization of space. On one hand the provisions of its key instruments offer broad interpretational leeway for and against the militarization and weaponization of space, while on the other hand, cyber warfare itself sits uneasily within the U.N. Charter on the regime on the use of force in light of the Charter drafters' almost singular fixation on conventional land, air and sea warfare.

This article seeks to bring to light the various aspects pertaining to the militarization and weaponization of space. ${ }^{9}$ It will give an overview of initiatives by the space-faring nations in developing space weaponry, discuss the space law regime and in particular expose its defects in effectively addressing space warfare. It will then proceed to generally juxtapose space warfare with the U.N. Charter regime on the use of force. The article exposes various questions, but does not seek to undertake the ambitious goal of supplying solutions; after all, as the article will demonstrate, the problems are readily evident, but the solutions absent.

\section{DEVELOPING COMBAT CAPABILITIES IN SPACE: FROM SCIENCE FICTION TO MILITARY UTILITY}

Despite the various prohibitions spelt out in declarations, proclamations and treaties, the United States and Soviet Union actively sought to harness the military capabilities offered by the

\footnotetext{
${ }^{9}$ The term "militarization," as applied to outer space, should not be confused with "weaponization." Though there are no authoritative international definitions of either term, the former refers to "the use of outer space by a significant number of military spacecraft" while the latter "refers to the placing in outer space for any length of time any device designed to attack man-made targets in outer space and/or in the terrestrial environment." Ivan A. Vlasic, Space Law and the Military Applications of Space Technology, in PERSPECTIVES ON INTERNATIONAL LAW 386 n.6 (N. Jasentuliyana ed., 1995).
} 
weaponization of space through development of offensive and defensive weaponry. During the late 1950s and early 1960s several air-launched anti-satellite weapons (A.S.A.T.) systems were tested by the United States and Soviet Union as a counter weight to each other's development of strategic air-launched and satellite-dependent ballistic missiles.

The United States initially led the way in exploring and researching innovative technology to develop military space plane technologies and a viable military space plane base. These efforts include:

[T]he first Aerospaceplane program and Dyna-Soar/X-20 program (late 1950s-early 1960s); X15 hypersonic and X-24 lifting body flight test programs (late 1950s through early 1970s); Advanced Military Space Flight Capability (AMSC), Transatmospheric Vehicle (TAV), and Military Aerospace Vehicle (MAV) concept and mission studies (early 1980s); the Copper Canyon airbreathing single-stage-to-orbit (SSTO) feasibility assessment and the National Aerospace Plane (NASP) program (1984-1992);...and, most recently, the Ballistic Missile Defense Organization's Single-Stage Rocket Technology program that built the Delta ClipperExperimental (DC-X) experimental reusable spaceplane. ${ }^{10}$

The Soviet Union was not to be outdone by the United States. It actively pursued development of anti-satellite weapons. ${ }^{11}$ By the 1970s, the Soviet Union had succeeded in developing an explosive kill vehicle with the ability to be "hoisted" into the same orbital plane as a target satellite. In addition, development of electromagnetic and radiation weapons with the capacity to impair electronic circuitry by the creation and/or emission of electromagnetic pulse (E.M.P.) was actively underway and yielding exciting results. Technological breakthroughs were turning scientific dreams into military utility. ${ }^{12}$

\footnotetext{
${ }^{10}$ GlobalSecurity.org, Military Spaceplane, at http://www.globalsecurity.org/space/systems/msp.htm.

${ }^{11}$ A.S.A.T.s are a form of "hard kill" weapon which entails steering the weapon close to the target and detonation in the vicinity to cripple the target. Through the 1960s, the Soviet Union wrestled with the technology and engineering necessary to bring into operation working A.S.A.T.s.

${ }^{12}$ This was manifest in the suspicious "blinding" of three United States satellites by an intense beam of radiation emanating from the western part of the Soviet Union in the autumn of 1975. Christopher M. Petras, The Use Of Force In Response To Cyber-Attack On Commercial Space Systems-Re-examining “Self-Defense” In Outer Space
} 
In the early 1970 s to mid-1970s, a period of détente set in, marginally easing the arms race between the two superpowers. This brief period of optimism and cooperation resulted in the signing of the Anti-Ballistic Missile and the Strategic Arms Reduction Treaties. ${ }^{13}$ However, as this period withered away, a renewed focus on space weaponry took over, leading then United States President Gerald Ford to sign the National Security Decision Memorandum No. 345 (N.S.D.M.-345) on January 18, 1977. N.S.D.M.-345 directed the Department of Defense (D.o.D.) to develop operational A.S.A.T. capability, while continuing to study arms control options for anti-satellite weapons. ${ }^{14}$

The argument behind the policy was both logical and persuasive: the prospect of a United States ASAT capability would serve as a "bargaining chip" that would provide the Soviet Union with real incentive to negotiate and give the United States leverage once talks began, and, in the event negotiations failed, the United States would acquire the capability to deal with military threats in space. $^{15}$

When Jimmy Carter stepped into the White House on Ford's departure, he embraced the Ford administration's "two-track" schizophrenic policy. On one hand, his administration sought to develop an operational United States A.S.A.T. capability; on the other hand, it pursued an agenda of limiting development of anti-satellite weapons by the Soviet Union. On May 11, 1978, Carter issued his own space policy through Presidential Directive (P.D./N.S.C. 37). ${ }^{16}$ It strongly mirrored that of the Ford administration and offered no significant new dimensions. Echoing the Ford administration's basic principle, it noted: "Purposeful interference with operational space

In Light Of The Convergence Of U.S. Military And Commercial Space Activities, 67 J. AIR L. \& CoM. 1213, 1224 (2002).

${ }^{13}$ Treaty on the Limitation of Anti-Ballistic Missile Systems, May 26, 1972, U.S.-U.S.S.R., 23 U.S.T. 3435 [hereinafter A.B.M. Treaty]; Interim Agreement Between the United States of America and the Union of Soviet Socialist Republics on Certain Measures with Respect to the Limitation of Strategic Offensive Arms, May 26, 1972, U.S.-U.S.S.R., 23 UST 3462 [hereinafter S.A.L.T. I].

${ }^{14}$ National Security Decision Memorandum No. 345, U.S. Anti-Satellite Capabilities.

${ }^{15}$ Petras, supra note 12, at 1224.

16 Presidential Directive N.S.C.-37, National Space Policy (May 11, 1978), available at http://www.hq.nasa.gov/office/pao/History/nsc-37.htm (last visited Aug. 8, 2002). 
systems shall be viewed as an infringement upon sovereign rights. The United States will pursue activities in space in support of its right of self-defense." $" 17$

Three years later, Carter was out of office and the bellicose Ronald Reagan the new occupant of the White House. Under Reagan, a significant shift in space policy was to take place. In 1981, the first year of the Reagan presidency, the new administration initiated a comprehensive space policy review geared towards exploring ways of generating a United States military capacity to weaponize space. Amidst the review, the Soviet Union introduced the prevention of an arms race in outer space into the agenda of the thirty-sixth General Assembly in the fall of $1981 .^{18}$ The Soviets proposed the conclusion of a Treaty on the Prohibition of the Stationing of Weapons of Any Kind in Outer Space. ${ }^{19}$ The General Assembly was receptive to the Soviet initiative and expressed the view that it "considered it necessary to take effective steps, by concluding an appropriate international treaty, to prevent the spread of the arms race to outer space." ${ }^{20}$ However, the initiative was received a lukewarm approach and was soon dead without mourners or honor.

In 1982, the results of the Reagan administration's comprehensive space review were presented in National Security Decision Directive No. 42 (N.S.D.D. 42), issued on July 4, 1982. ${ }^{21}$ Its key theme reiterated that contained in the previous Ford and Carter administrations - the United States considered the space systems of any nation to be national property with the right of passage through space without interference. Purposeful interference with space systems would be

\footnotetext{
${ }^{17} I d$.

${ }^{18}$ Request for the Inclusion of a Supplementary Item in the Agenda of the Thirty-Sixth Session, United Nations General Assembly, U.N.Doc. A/36/192 (1981).

${ }^{19}$ Id.

${ }^{20} \mathrm{Id}$.

21 National Security Decision Directive No. 42, National Space Policy (Jul. 4, 1982), available at http://www.nasa.gov/office/codez/new/policy/nsdd-42.htm (last visited Aug. 8, 2002).
} 
viewed as infringement upon sovereign rights. ${ }^{22}$ It was, however, the D.o.D. space policy issued a few days later that signaled a significant shift in policy. It heralded the development of an A.S.A.T. capability for the primary purpose of "[deterring] threats to [the] space systems of the United States and its allies." 23 A year later, it was "gloves-off" time when Reagan launched the Strategic Defense Initiative (S.D.I.) on 23 March 1983. Reagan delivered what became "known as 'The Star Wars Speech' in which he proposed using technological advances to develop an effective non-nuclear missile defense program to counter missiles launched by attackers." ${ }^{24}$ In it he further announced the ambitious military goal of the United States to "embark on a program to counter the awesome Soviet missile threat with measures that are defensive." ${ }^{25}$ The focus of the S.D.I. program was to intercept and destroy strategic ballistic missiles before they reached continental United States. ${ }^{26}$ The S.D.I. was a system geared to use space-based systems to protect the United States from attack by strategic nuclear missiles. The "Star Wars" initiative gave the cooling space arms race a renewed boost. ${ }^{27}$

The S.D.I received an added boost in July 1982 when the Reagan Administration released the "Defense Guidance" directive which unabashedly proclaimed that "the United States will pursue activities in support of its right to self-defense." ${ }^{28}$ It offered a five-year plan in which space operations would "add a new dimension to our military capabilities." 29 The directive also ordered "the prototype development of space-based weapons systems so that [the U.S.] will be

\footnotetext{
${ }^{22} I d$.

${ }^{23}$ See Paul B. Stares, SpaCe AND National SeCURITy 218 (1987).

${ }^{24}$ Jonathan N. Halpern, Antisatellite Weaponry: The High Road to Destruction, 3 B.U. INT'L L.J. 167, 175 (1985).

${ }^{25}$ President Ronald Reagan's speech, N.Y. TIMES, Mar. 24, 1983, at A20.

${ }^{26} I d$.

${ }^{27}$ Major S. Anderson notes, "[t]he SDI provided a measure of legitimacy to many ideas that were formerly seen as impossible." Major Douglas S. Anderson, A Military Look into Space Law: The Ultimate High Ground, Nov. ARMY LAW 19, 22 (1995).

${ }^{28}$ July 1982 Presidential Directive on National Space Policy, reported in N.Y. TIMES, Mar. 27, 1983, at A1, col. 6. ${ }^{29} I d$.
} 
prepared to deploy fully developed and operationally ready systems should their use prove to be in [its] national interest." 30

With the S.D.I. in place and Reagan's militaristic mindset, billions of dollars were splashed on various military projects, mainly innovative technologies to bolster the military might of the United States. The United States was keen to develop and introduce futuristic weapons, including beam, kinetic, electronic, and laser weapons into the space environment. There was however considerable debate over the necessity, feasibility, and cost-effectiveness of such weapons. The huge military expenditure did pay dividends. Among its major successes was the flight in September 13, 1985 by United States Air Force pilot Major Doug Pearson. He made military history when he successfully displayed the capabilities of A.S.A.T. weapons:

From his F-15A flying at Mach1.22 200 miles west of Vandenberg AFB, he executed a $3.8 \mathrm{~g} 65$ degree climb to launch a missile, which destroyed a satellite called P78-1. The target satellite was orbiting at 345 miles above the Pacific Ocean. The target satellite was kinetically destroyed, shattered into space debris. ${ }^{31}$

Pearson's feat provided credence as well as a propaganda base for the Reagan administration's "Star Wars" vision, signaling a new phase in the arms race in outer space. The successful flight provided just the sort of evidence that proponents of the weaponization of space needed. It was evident that a robust, well-funded space program would be able to develop workable technologies.

Even as the Reagan administration was turning the heat up with its ambitious space militarization and weaponization vision, the United Nations Committee on the Peaceful Uses of Outer Space (COPUOS) was working to address the matter of weaponization of space anhd in

\footnotetext{
${ }^{30} I d$.

${ }^{31}$ Michel Bourbonnière, Law of Armed Conflict (LOAC) and the Neutralisation of Satellites or Ius in Bello Satellitis, 9 J. CONFLICT \& SECURITY L. 43, 56 (2004).
} 
particular to head off the looming space arms race between the two superpowers. In its report issued at the end of its 1985 session, COPUOS acknowledged the differing viewpoints by member states as to the extent to which the Committee could engage in substantive work toward the peaceful maintenance of outer space. ${ }^{32}$ The COPOUS initiative was among a series of international initiatives in the shadow of the "Star Wars" program aimed at curtailing the Reagan administration's gung ho mindset towards outer space.

Three years after the COPOUS meeting, in 1988 the General Assembly passed a resolution supporting general and complete disarmament under effective international control. ${ }^{33}$ Resolution 43/70 stated that in order for disarmament to take place, outer space must be used for peaceful purposes and must not become an arena for a new arms race. "The General Assembly recognized the need to consolidate, reinforce, and enhance the legal regime in outer space, and to provide effective verification measures. The vote on the resolution was 154 to 1: the United States cast the single negative vote." 35 The prevention of an arms race in outer space was once again at the heart of the deliberations of the Conference on Disarmament composed of both developed and developing world countries when it convened for its 520th plenary meeting in 1989. Delegates called for the prevention of an arms race in outer space. The general sentiments of the meeting are captured in Indian Ambassador Sharma's declaration that:

[I]t is accepted that an extension of the arms race into outer space would have profoundly destabilizing consequences. Deeply conscious of such risks, an overwhelming majority of the Member States of the United Nations have in recent years urged the Conference on Disarmament to take resolute measures aimed at preventing an arms race in outer space. ${ }^{36}$

\footnotetext{
32 Committee on the Peaceful Uses of Outer Space, Twenty-Eighth Session, 278th Meeting and Round-Up of Session, U.N.Doc. A/AC.105/L.155; Round-up of Session, U.N. Press Release OS/1210/Rev. 1 (June 28, 1985).

${ }^{33}$ Prevention of an Arms Race in Outer Space, U.N. GAOR, $1^{\text {st }}$ Comm., G.A.Res. 43/70 (1988).

${ }^{34} I d$. (emphasis added).

35 Colleen Driscoll Sullivan, The Prevention of an Arms Race in Outer Space: An Emerging Principle of International Law, 4 TEMP. INT'L \& COMP. L.J. 211, 234 (1990).

${ }^{36}$ Conference on Disarmament, Final Record of the 529th Plenary Meeting, U.N.Doc. CD/PV.529 (1989).
} 
However the differing viewpoints among some members and the political shadow cast by the reluctant superpowers prevented any definitive agenda emerging in relation to preventing weaponization of outer space, something which may perhaps have put a brake on the Reagan administration's "Star Wars" vision and thrown cold water on Soviet determination to match and counter the Reagan administration's ambitious program.

By 1989, the Reagan policy of "A.S.A.T. deterrence," and the corresponding goal of developing and deploying anti-satellite capability, were reaffirmed and entrenched as part of United States military policy with the introduction of National Space Policy Directive No.1 (N.S.P.D. 1) by the George Bush Sr. administration. The move to ensure effective global power projection through space supremacy received added urgency a year later, in 1990, when the first Gulf War demonstrated the multiplier effects that space technology would have on military capabilities.

The article now turns to consider the impact that the first Gulf War had on United States space policy. It was the first war to rely heavily on space technology and the first to demonstrate that an integrated battle platform coordinated through space assets would contribute tremendously to battleground supremacy. The net result in subsequent years was to spur the United States to aggressively pursue research and development of innovative space weapons and in particular the development of Space Operated Vehicles (S.O.V.s) with the capability of delivering and deploying ordnances from space through low-earth orbit (L.E.O.), geosynchronous orbit (G.E.O.) or sun-synchronous orbit (S.S.O.). 


\section{THE FIRST GULF WAR: "DWARFING" THE ENEMY THROUGH SPACE SUPREMACY}

The first Gulf War ("Operation Desert Storm") heralded the beginning of a great era of the space age. ${ }^{37}$ "It's the first space war," declared a space policy analyst. ${ }^{38}$ Coalition forces, which included the largest naval fleet constituted since World War II, were supported by "the most sophisticated information network ever designed...dwarfing anything generated in previous wars. ${ }^{39}$ An impressive array of technologies, and particularly the use of satellites and other outer-space mounted devices, was on display. The United States displayed that space technology would be harnessed to coordinate land, sea and aerial military assets to produce a holistic integrated battle platform. The "Smart War" featured lightening attacks targeting Iraqi command and control targets, ${ }^{40}$ and "microwave" technology targeting and jamming Iraqi communications facilities. ${ }^{41}$ The future was now here.

The experience of the Gulf War in which the United States suffered light casualties despite facing a battle-hardened Iraqi Army and the role that technology played in enabling its control of the battlefield buoyed United States determination to enhance its military capabilities through technology. The heavy reliance on satellites convinced the United States military that "space dominance and space control" were necessary. ${ }^{42}$

\footnotetext{
${ }^{37}$ Walter D. Reed \& Robert W. Norris, Military Use of the Space Shuttle, 13 AKRON L. REV. 665 (1979).

${ }^{38}$ John Pike, Federation of American Scientists, quoted in Vincent Kiernan, War Tests Satellites' Prowess, Military Space Systems Put to Work during Desert Storm Conflict, SpaCe News, Jan. 21, 1991. See also John J. Meyer III, JTF Communications: The Way Ahead, MIL. REV., Mar. 1993, at 85.

${ }^{39}$ John H. Petersen, Info Wars, NaVAl Inst. Proc., NAVAl ReV. 88, 96 (May 1993).

${ }^{40}$ Military Eyes CRAF-like System for Commercial Satellites, AEROSPACE NEWS , Feb. 21, 1992, at 285.

${ }^{41}$ Kathleen Killette, Iraq Net Critical Target, CoMM. WK., Jan. 21, 1991, at 60.
}

[T] he war was essentially an opportunity to test new weapons systems. Afterward, Pentagon spokespersons predicted that if other enemies could be prevented from gaining access to military space assets, the US could dominate any battlefield situation. An urgent call went out for antisatellite weapons that could knock out competitors' eyes and ears. 
It was not lost on the Pentagon that while the Air Force's Air Expeditionary Force (A.E.F.) can bring to bear weighty ordnance from heavy bombers, its long cycle time between missions, particularly if traveling from continental United States, posed a logistical nightmare with possession of few overseas bases exacerbated by the frequent denial of over-flight rights. This tended to restrict missions or force military command into alternative plans. These shortcomings meant that the United States was forced to rely heavily on the Navy's Carrier Battle Groups (C.V.B.G.) to take up missions. However, the C.V.B.G. had their own problems, mainly the time taken to reach the operational area, the expense of cruise missiles, the limited number of available cruise missiles and their limited ability to strike mobile or heavily fortified targets.

Six years after the experiences of the first Gulf War, then United States President Bill Clinton issued his national space policy. In part, it carried on the general tenor of United States space policy stretching back to the Ford years. It reiterated the requirement that space was to be used for "peaceful purposes." However, it contained a robust reaffirmation of the shift in policy that had been spawned by Reagan. It championed the interpretation that the term "peaceful" does not exclude military activity such as intelligence-gathering or even armed defense. ${ }^{43}$ The policy went on to note the military utility of space asserting that "peaceful purposes" encompassed defense and intelligence-related activities in pursuit of national security and other goals. ${ }^{44}$ Two years later, Clinton's National Security Strategy asserted that "[US] policy is to promote development of the full range of space-based capabilities in a manner that protects our vital national security interests." 45 Two significant reasons may be attributed to this strong pro-

Quoted in Bruce K. Gagnon, Pyramids to the Heavens: The Coming Battle for Control and Exploitation of Space, in 48 TOWARD FREEDOM 1 (Sept./Oct. 1999), available at http://www.towardfreedom.com/1999/sep99/spacewar.htm.

43 National Science and Technology Council, National Space Policy 3 (Sept. 19, 1996), at http://ast.faa.gov/licensing/regulations/nsp-pdd8.htm (emphasis added).

${ }^{4} \mathrm{Id}$.

${ }^{45}$ A National Security Strategy for a New Century (The White House, Office of the President 1998) at 25 (emphasis added). 
military stance. First, since the first Gulf War, the United States had been pursuing development of space air vehicle systems and the United States Air Force's dream of a responsive Military Space plane - the S.O.V.- - was firming up as a reality as a result of major technological and engineering breakthroughs. ${ }^{46}$ Secondly, there was a military worry that the new heavy reliance on space was creating significant vulnerabilities to United States' military operations. ${ }^{47}$

In 2001, Clinton exited the White House and George Bush Jr. took over the reins. While the Clinton administration had advocated a robust space policy, Clinton (in the tradition of the Democrats) had demonstrated disinclination towards a heavy military spending binge. Bush Jr., however, showed no such caution. In line with former Republican president, Ronald Reagan, he revived and adopted a bellicose, hard-line stance based on the notion that America's interests were underwritten by military might, and thus the need to not only maintain America's supremacy but to eclipse every other nation. Technological breakthroughs in the 1990s had brought to the fore the fact that the heavens would not only be conquered but ruled. Shrugging the protest of the international community, the Bush Jr. administration dusted off Reagan's S.D.I. and brought it back to play with the embrace of the so-called "Son of Star Wars".

In 2001, a Commission chaired by Donald Rumsfeld - a space weaponry fanaticreported to Congress after a comprehensive space review. The report warned that the 600 satellites the United States military depends upon for photo reconnaissance, targeting, communications, weather forecasting, early warning and intelligence gathering were highly

\footnotetext{
46 The S.O.V. is a multipurpose rugged L.E.O. capable vehicle designed to conduct sustained routine space operations such as replacing satellite assets and reconnaissance but significantly with the ability to conduct multiple sorties for military purposes. See Lieutenant Phillip E. Pournelle, Component Based Simulation of the Space Operations Vehicle and the Common Aero Vehicle, Master of Operations Analysis (1999) (unpublished thesis, Naval Postgraduate School, Monterey, California), available at diana.gl.nps.navy.mil/ ahbuss/StudentTheses/PournelleThesis.pdf.

47 "Suddenly, one of the best ways to disrupt a United States military offensive by jamming the satellites on which the Americans rely or blowing up the ground stations back in the United States that control the satellites transmitting targeting data": Jonathan Broder, Why Are We Preparing for War in Space? (2001) available at http://www.cyberspaceorbit.com/warinspc.htm.
} 
vulnerable to attack from adversaries. ${ }^{48}$ The report went on to caution that the United States must anticipate a "Space Pearl Harbor"-a crippling sneak attack against American satellites orbiting the planet. $^{49}$ To reduce the nation's vulnerability, the Rumsfeld Commission urged the government to develop "superior space capabilities," including the ability to "negate the hostile use of space against United States interests" by using "power projection in, from and through space." ${ }^{50}$ With the Bush Jr. administration pledging to pursue a national missile defense system, Rumsfeld's vision was to guarantee dominance of space by eliminating threats to America's satellites. $^{51}$ Rumsfeld noted that from history every medium-air, land and sea-had seen conflict. In essence, contemporary reality indicates that space will be no different. ${ }^{52}$ The report from his Commission rounded off by calling space warfare "a virtual certainty."

It was not just the Americans who were seeing space warfare as a virtual certainty in the future. The first Gulf War had convinced China's military leadership of the importance of hightech warfare and the ability of sophisticated space-based command, control, communications, and intelligence systems to link land, sea and air forces. ${ }^{53}$ The growing importance of space in future warfare left the Chinese with no choice but to take note of United States military efforts to ensure future space dominance. With Russia a washed out power lacking the financial resources to keep up the "toe to toe" space arms race with the United States, China as an aspiring superpower has been quick to join the game.

\footnotetext{
${ }^{48}$ Report of the Commission to Assess United States National Security Space Management and Organization (Jan. 11, 2001), available at http://www.defenselink.mil/pubs/space20010111.html.

${ }^{49} I d$.

${ }^{50} \mathrm{Id}$.

${ }^{51}$ Broder, Why Are We Preparing for War in Space?, supra note 47.

52 Supra note 48.

${ }^{53}$ Wang Xiaodong, Special Means of Warfare in the Information Age: Strategic Information Warfare, JIANCHUAN ZHISHI [WARSHIP INFORMATION], June 30, 1999, in FBIS-FTS19990727000426 and FBIS-FTS19990727000941; Wang Baocun, Subduing Enemy Force Without Battle and Informationized Warfare, ZHONGGUO JUNSHI KEXUE [ChINA MilitARY SCIENCE], May 4, 1999, 60-63 in FBIS-FTS19990823000602; James D. Perry, Operation Allied Force: The View from Beijing, 14(2) AEROSPACE POWER J. 79 (2000).
} 


\section{CHINA-A NEW CHALLENGER STEPS FORWARD: THE DRAGON LOOKS UP TO THE HEAVENS}

Having watched the United States harness the effectiveness of an integrated battleground platform underpinned by space technology and weaponry in the first Gulf War, Chinese defense analysts recognized that space control provides the key to military victories in modern warfare.

As a consequence, China has in recent years been concentrating on sharpening its military power through incorporation of technology geared toward a leaner and efficient technologically driven military. This is in part due to five factors.

1. the technical and professional reforms of the 1980s which sought to de-politicize the military allowing it to focus more robustly on its core business - effective warfare capability. ${ }^{54}$

2. the learning experience from the use of space technology by the United States in both Gulf Wars and Kosovo.

3. an awareness that the benignly labeled Japanese Self-Defense forces of its chief competitor in Asia have a serious technological edge. ${ }^{55}$

4. the Bush Jr. administration's push to implement a national ballistic missile shield and significantly the potential provision of this technology to Taiwan in an atmosphere of increased tension between the tiny island state and mainland China.

5. its aspirations to superpower status, helped in no small measure by the vacuum created by the break-up of the Soviet Union, its chaotic and inept transition to free market economy that has hamstrung it economically resulting in a significant decay of its military capabilities.

In view of the factors outlined above, it was not surprising that in 2003, a Chinese military official declared: "In the current and future state security strategy, if one wants not to be controlled by others, one must have considerable space, scientific and technological strength. Otherwise one will be bullied by others." 56

\footnotetext{
${ }^{54}$ Harlan W Jencks, China's Army, China's Future, in CHINA IN THE NinETIES: CRISIS MANAGEMENT AND BEYOND 131-159 (David S. G. Goodman \& Gerald Segal eds., 1991).

${ }^{55}$ William S. Murray III and Robert Antonellis, China's Space Program: The Dragon Eyes the Moon (and Us), ORBIS 645, 649 (2003) (copy on file with author).

${ }^{56}$ China Plans First Manned Space Launch in October, AgENCE PRESSE FrANCE, Jan. 17, 2003.
} 
China's position as a space power was cemented with the successful launch of its first manned spaceflight into the earth's orbit on February 15, 2003. China became only the third nation to achieve the feat. In tandem with this, it has undertaken an active role in sharpening its war fighting space skills, from creating anti-satellite weaponry, building new classes of heavy-lift and small boosters, as well as improving an array of military space systems. It is no secret that China has long harbored long-term plans to launch its own space station, and possibly a reusable space plane as well. While one of the strongest immediate motivations for this program appears to be political prestige, China's manned space efforts are almost certainly geared to contribute to improved military space systems. ${ }^{57}$

Publicly, China "declares that space should not be militarized and that space technologies should be used for peaceful purposes." ${ }^{, 58}$ This stance mirrors the sentiments of the other major space-faring states. Similar to the United States and the former Soviet Union, the Chinese rhetoric is clearly at odds with the military considerations driving its space program. The Chinese space program's mid-term objectives include creating an integrated military earth observation system, building satellite broadcasting and telecommunications system $^{59}$ and fielding a constellation of space-based reconnaissance systems with real-time intelligence capabilities. ${ }^{60}$ Keen to bolster its electronic "eyes and ears":

In the booster department, China is proceeding with building a new modular family of heavy-lift launchers. Additionally, a new small, solid-propellant space lifter is being developed. A family of these smaller boosters would provide China the ability to hurl small satellites into orbit. This

\footnotetext{
57 Annual Report On The Military Power of the People's Republic of China, Report to Congress Pursuant to the FY2000 National Defense Authorization Act (June 2000), available at Www.csis.org/burke/mb/asia_neac_dod_china.pdf.

${ }_{58}$ Murray and Antonellis, supra note 55, at 649.

${ }^{59}$ China and Weapons of Mass Destruction: Implications for the United States, Conference sponsored by the U.S. National Intelligence Council (N.I.C.) and the Federal Research Division (F.R.D.), Library of Congress, Nov. 5, 1999.

${ }^{60}$ Mark A. Stokes, China's Strategic Modernization: Implications for the United States, STRATEGIC STUD. INST., Sept. 1999.
} 
class of booster would give China a rapid launch capability, "and has broad military, civil, and commercial applications." 61

China has been busy procuring state-of-the-art technology to improve its intercept, direction finding, and jamming capabilities. China is also on a path toward developing directascent A.S.A.T. system. A Pentagon report in 1998 warned that "given China's current level of interest in laser technology, it is reasonable to assume that Beijing would develop a weapon that could destroy satellites in the future." ${ }^{62}$ This was no idle warning: "in 1999, the Chinese displayed a portable laser weapon, advertised for blinding human vision and electro-optical sensors highlighting a potential acquisition of high-energy laser equipment that could be used in the development of ground-based A.S.A.T. weapons. ${ }^{" 63}$ Despite the Communist regime's traditional aversion to transparency, China seems to have also developed satellite tracking radar, as well as anti-G.P.S. jamming technology. ${ }^{64}$

The next part of the article conducts a brief tour de horizon of the space law regime. It does not seek to analyze the regime in full; rather, it will confine itself to an overview of international initiatives that have had a somewhat direct bearing on the weaponization and militarization of space. The international instruments in question are the 1963 Limited Test Ban

\footnotetext{
${ }^{61}$ Annual Report on the Military Power of the People's Republic of China, supra note 57.

${ }^{62}$ Bill Gertz, Chinese Army is Building Laser Weapons, WASH. TIMES, Nov. 3, 1998.

21 Paul Richter, China May Seek Satellite Laser, Pentagon Warns, N.Y. Times, Nov. 28, 1998.

${ }^{63}$ Leonard David, Pentagon Report: China's Space Warfare Tactics Aimed at U.S. Supremacy, 1 August 2003 available at $\mathrm{http} / / / \mathrm{www}$. space.com/news/china_dod_030801.html.

${ }^{64}$ Annual Report on the Military Power of the People's Republic of China, supra note 57.
} 
Treaty, ${ }^{65}$ the 1967 Outer Space Treaty, ${ }^{66}$ the 1972 Anti-Ballistic Missile Treaty (A.B.M. Treaty) ${ }^{67}$ and the first Strategic Arms Reduction (S.A.L.T.) Treaty. ${ }^{68}$

\section{A NEW CALCULUS-SPACE LAW: MANAGING AN EXTRA-TERRESTIAL WILD WEST}

In the late 1950s, states maintained the view that outer space should be used for "peaceful" purposes. However, the disagreement was whether this meant "non-military" or "nonaggressive uses," especially considering the fact that the then-dominant players-the two superpowers - were actively engaged in harnessing the military utility offered by space and were thus averse to a strict definition. The space regime as it now exists rests upon five United Nations treaties on outer space. These treaties evolved from a series of General Assembly resolutions and declarations following the creation of the Outer Space Committee in $1959 .{ }^{69}$

The development of a legal regime to govern space was kick-started in 1963 with the adoption of the Declaration of Legal Principles Governing State Activity in the Exploration and

\footnotetext{
${ }^{65}$ Treaty Banning Nuclear Weapon Tests in the Atmosphere, in Outer Space and Underwater, Aug. 5, 1963, 14 U.S.T. 1313, 480 U.N.T.S. 43 (entered into force Oct. 10, 1963).

${ }^{66}$ Treaty on Principles Governing the Activities of States in the Exploration and Use of Outer Space, Including the Moon and Other Celestial Bodies, Jan. 27, 1967, 18 U.S.T. 2410, 610 U.N.T.S. 205.

${ }^{67}$ Treaty on the Limitation of Anti-Ballistic Missile Systems, May 26, 1972, U.S.-U.S.S.R., 23 U.S.T. 3455, T.I.A.S. No. 7503 (effective Oct. 3, 1972).

${ }^{68}$ Treaty on the Limitation of Anti-Ballistic Missile Systems, May 26, 1972, U.S.-U.S.S.R., 23 U.S.T. 3435 [hereinafter A.B.M. Treaty]; Interim Agreement Between the United States of America and the Union of Soviet Socialist Republics on Certain Measures with Respect to the Limitation of Strategic Offensive Arms, May 26, 1972, U.S.-U.S.S.R., 23 UST 3462 [hereinafter S.A.L.T. I].

${ }^{69}$ Treaty on Principles Governing the Activities of States in the Exploration and Use of Outer Space, Including the Moon and Other Celestial Bodies; Agreement on the Rescue of Astronauts, the Return of Astronauts and the Return of Objects Launched into Outer Space; Convention on International Liability for Damage Caused by Space Objects; Convention on Registration of Objects Launched into Outer Space; Agreement Governing the Activities of States on the Moon and Other Celestial Bodies; Agreement on the Rescue of Astronauts, the Return of Astronauts, and the Return of Objects Launched into Outer Space, entered into force Oct. 10, 1967, 19 U.S.T. 7570, T.I.A.S. No. 6599, 672 U.N.T.S. 119; Convention on International Liability for Damage Caused by Space Objects, entered into force Sept. 1, 1972, 24 U.S.T. 2389, T.I.A.S. No. 7762; Convention on Registration of Objects Launched into Outer Space, entered into force Sept. 15, 1976, T.I.A.S. No. 8480; Agreement Governing the Activities of States on the Moon and Other Celestial Bodies, U.N. Doc. A/34/20 (1979).
} 
Use of Outer in late 1963 by the United Nations General Assembly. ${ }^{70}$ It was the "first significant step in the development of space law". ${ }^{71}$ In the same year that the Declaration on Legal Principles was adopted, the Treaty Banning Nuclear Weapons in the Atmosphere, In Outer Space and Under Water (Limited Test Ban Treaty) ${ }^{72}$ entered into force to address the contested and controversial issue of nuclear detonations in space. The treaty primarily aimed to limit nuclear weapons testing but was also a reaction to Soviet pleas that nuclear detonations posed a danger to the safety of its cosmonauts. ${ }^{73}$ Though the United States responded to the Soviet concern with the assurance "that no activities were contemplated which could have harmful effects upon the Soviet spacemen,",74 the international community nonetheless felt it imperative that nuclear detonations be totally banned. With the entry into force of the Limited Test Ban Treaty, nuclear detonations in space were no longer lawful. ${ }^{75}$ In addition, the treaty establishes three significant implications for space warfare. These are eloquently synthesized by Major Robert A. Ramsey:

1. First, while the treaty prohibits all nuclear detonations in space, even those that may have value for peaceful military or scientific purposes, it does not regulate detonations of a nonnuclear nature.

2. Second, because the treaty outlaws 'any nuclear weapon test explosion, or any other nuclear explosion', it may prohibit the use of nuclear fission as a means of space propulsion.

3. Finally, the Treaty also prohibits the use of nuclear explosions for non-testing purposes as well. $^{76}$

\footnotetext{
${ }^{70}$ Declaration of Legal Principles Governing the Activities of States in the Exploration and Use of Outer Space, G.A. Res. 1962, U.N. GAOR, 18th Sess., Supp. No. 15 at 15, U.N. Doc. A/5515 (1963).

${ }^{71}$ Major Robert A. Ramsey, Armed Conflict on the Final Frontier: The Law of War in Space 48 A.F.L. REV. 1, 110 (2000).

72 Treaty Banning Nuclear Weapon Tests in the Atmosphere, in Outer Space and Underwater, Aug. 5, 1963,14 U.S.T. 1313, 480 U.N.T.S. 43 (entered into force Oct. 10, 1963).

${ }^{73}$ Ramsey, supra note 71, at 12-13.

${ }^{74}$ MCDOUGAL, ET AL., supra note 5, at 389 n.7.

75 The U.S. "Vela Hotel" satellites were launched in 1963 and 1964 to scan above the horizon and detect nuclear tests in space. They were, in the view of one military space historian, "one of the most successful Air Force space projects": Curtis Peebles, High Frontier: THE U.S. AIR FORCE AND THE MilitARY SPACE PROGRAM 41 (1997).

${ }^{76}$ Ramsey, supra note 71, at 100-101.
} 
The treaty's singular focus on nuclear detonations was a sign of its time. Little thought and attention seems to have been put into ensuring that the treaty effectively prevented space from being turned from a sanctuary of "peaceful" science into a battleground that may one day offer opportunities for offensive and defensive non-nuclear weapons. First, the ban focuses exclusively on nuclear weapons, meaning that other forms of weapons such as conventional, biological, chemical, or high energy laser weapons can be deployed without breaching the treaty. Second, to the extent that nuclear power sources operate by means other than explosion, the treaty does not prohibit their use. This off course means that the testing and deployment of nonnuclear based A.S.A.T.s and S.O.V.s with combat capabilities are technically not covered by the treaty.

Four years after the entry into force of the Limited Test Ban Treaty, the Outer Space Treaty entered into force. This treaty has been termed the "Magna Carta of outer space law.",77 The major principles governing activities in space are presented in Articles I, II and III of the Outer Space Treaty. Article I states that activities in outer space, including the moon and other celestial bodies, shall be conducted for the benefit of all countries and that outer space shall be part of the heritage of all mankind. ${ }^{78}$ It also provides for freedom of scientific investigation in outer space and for international cooperation in such investigation. ${ }^{79}$ Article II provides that nations cannot appropriate outer space by claim of sovereignty. ${ }^{80}$ Article III provides that states parties to the Treaty will conduct their activities in space in accordance with international law, the United Nations Charter, and in the interest of international peace, security, cooperation and

\footnotetext{
${ }^{77}$ N. Jasentuliyana, The Role of Developing Countries in the Formation of Space Law, 20(2) ANNALS AIR \& SPACE L. 95, 97 (1995).

${ }^{78}$ Outer Space Treaty, supra note 66, art. 1.

${ }^{79} I d$., art. 1.

${ }^{80} I d$., art. 2.
} 
understanding. ${ }^{81}$ Of significance with regard to the use of force is Article III's reference to Article 51 of the United Nations Charter and in particular its express preservation of the right of states to use space in self-defense.

The most relevant provisions regarding weaponization of space are Articles IV and IX. Article IV provides:

\begin{abstract}
States Parties to the Treaty undertake not to place in orbit around the earth any objects carrying nuclear weapons or any other kinds of weapons of mass destruction, install such weapons on celestial bodies, or station such weapons in outer space in any other manner. The moon and other celestial bodies shall be used by all States Parties to the Treaty exclusively for peaceful purposes. The establishment of military bases, installations and fortifications, the testing of any type of weapons and the conduct of military manoeuvres on celestial bodies shall be forbidden. The use of military personnel for scientific research or for any other peaceful purposes shall not be prohibited. The use of any equipment or facility necessary for peaceful exploration of the moon and other celestial bodies shall also not be prohibited. ${ }^{82}$
\end{abstract}

The language in the provision above specifically refers to the limitation of nuclear weapons or any other kinds of weapons of mass destruction from being placed "in orbit around the earth ... install on celestial bodies ... nor station in outer space in any manner." 83 This language refers to nuclear weapons and other weapons of mass destruction specifically and not to peaceful purposes generally. In this regard, Anderson notes that "Article IV (1) is viewed by most commentators as only a limited disarmament provision." 84 The phrase "weapons of mass destruction" is generally accepted to include nuclear, chemical and biological weapons. ${ }^{85}$ This essentially means that the weapons of mass destruction provision does not apply to conventional weapons, nor does it

${ }^{81} I d$., art. 3.

${ }^{82}$ Id., art. 4 (emphasis added).

${ }^{83}$ Bin CHENG, Studies in INTERNATIONAL SpaCe LAW 150 (1997).

${ }^{84}$ Anderson, supra note 27, 23.

${ }^{85}$ See Robert L. Bridge, International Law and Military Activities in Outer Space, 13 AKron L. ReV. 649, 656 (1980) (referencing the Senate Foreign Relations Committee hearings on the Outer Space Treaty and the testimony of United Nations Ambassador Goldberg in response to a question by Senator Carlson that weapons of mass destruction "is a weapon of comparable ability of annihilation to a nuclear weapon, bacteriological ... [i]t does not relate to a conventional weapon"). 
apply to land-based intercontinental ballistic missiles. ${ }^{86}$ Evidence that the drafters only intended Article IV (1) to ban orbiting nuclear-type weapons is the drafters' agreement that the Treaty does not prohibit the stationing of land-based ICBMs, even though their flight trajectory would take them through outer space. ${ }^{87}$ It is well established that the only specific limitation placed on the use of the outer void space for military purposes is that found in Article IV (1). ${ }^{88}$ Professor Cheng asserts that "the outer void space as such can be used for any military activity that is compatible with general international law and the Charter of the United Nations, so long as no "nuclear weapons or any other kind of weapons of mass destruction are stationed there." 89 The practical import of this analysis is captured in Anderson's observation that:

\begin{abstract}
Under this...interpretation, none of the exotic future weapons systems currently being proposed or researched by the United States would violate this provision of the Outer Space Treaty. For instance, laser beam weapons are intended to destroy their targets by delivering a high impulse shock that causes structural collapse of the rocket booster or by remaining on the target until a hole is burned through the missile... violations would only occur if any of the weapon systems included a nuclear explosion to propel them or as a means of destroying a target. ${ }^{90}$
\end{abstract}

Alongside the specific reference the restriction of only particular weapons, Article IV is the setting for much greater controversy. It provides for two separate legal regimes for military activity in outer space: (1) activity conducted on the moon and other celestial bodies, and (2) activity conducted in outer space itself. Article IV divides the extraterrestrial universe into three parts: the Earth's orbit, celestial bodies, and outer space. This then means that the Outer Space Treaty does not completely free all of outer space from military use. Military activity by its

\footnotetext{
${ }^{86}$ According to one report, the "common definition" of "weapons of mass destruction" is nuclear bombs or warheads. N.Y. TIMES, Mar. 27, 1983, at A1, col. 6; See also Captain Michael G. Gallagher, Legal Aspects of the Strategic Defense Initiative, 111 MIL. L. REV. 11, 41 (1986) who notes the weapons of mass destruction provision is designed to prevent use of weapons that have an indiscriminate effect on large populations or geographical areas.

${ }^{87}$ Id. Other weapons of mass destruction not relevant to the issue of planetary defense would be biological and chemical weapons.

${ }^{88}$ See CHENG, supra note 83, 529

${ }^{89}$ CHENG, supra note 83.

${ }^{90}$ Anderson, supra note 27, 24-25.
} 
terms, including deployment of the A.S.A.T., is prohibited specifically on the moon and other celestial bodies. Outer space, as such, remains open to military activity that is non-aggressive, in line with the United Nations Charter, international law as long as such activity does not involve nuclear weapons or weapons of mass destruction. Professor Bin Cheng notes that subject to the second paragraph in article IV, "nothing in article IV (1) itself prohibits the stationing of any other type of weapons in outer space, including the moon and other celestial bodies, or in fact the use of outer space, including the moon and other celestial bodies, for military purposes in any other way."91

From the foregoing paragraphs, it can be deduced that Article IV of the Outer Space Treaty contemplates the military use of space for scientific research and grants a carte blanche to civilian scientific applications. The reality is that civilian applications of space capabilities such as weather, navigation, communications and remote sensing are equally significant for military purposes. In addition, as a technical matter, there is no bright line between military "missiles" and civilian "space launch vehicles." Technologies used to build sophisticated weaponry are often similar or even identical to the technologies required for civilian space programs. "The differences relate to intentions, not capabilities." 92

The tacit acceptance of military usages coupled with the explicit permission to civilian endeavors provides a strong argument that militarization of space through placement of nonnuclear and other weapons of destruction is in and of itself permissible under the space law regime. The argument then moves to whether the acceptance of space militarization under this interpretation permits the deployment of offensive and defensive capabilities in space in a variety

\footnotetext{
${ }^{91}$ Bin Cheng, The Legal Status of Outer Space and Relevant Issues: Delimitation of Outer Space and Definition of Peaceful Use, 11 J. SPACE L. 89, 101 (1983) (emphasis in original).

${ }_{92}$ Barry J. Huretwitz, Non-Proliferation and Free Access to Outer Space: The Dual-Use Dilemma of the Outer Space Treaty and the Missile Technology Control Regime, (1994) 9 HIGH TECH. L.J. 211 (1994).
} 
of respects. Pursuing this line of argument further, a military-biased interpretation of article IX of the Outer Space Treaty would seem to provide for the possibility of space combat in a variety of respects. It provides, in part: "States Parties to the Treaty shall be guided by the principle of cooperation and mutual assistance and shall conduct all their activities in outer space, including the moon and other celestial bodies, with due regard to the corresponding interests of all other States Parties to the Treaty." 93 The provision, like Article IV and for that matter most key space law provisions, makes no distinction between military and civilian activities. Based on this lack of clarity, and depending on the interpreter, the provision would apply fully to military operations in space. In any case, the United States has imported a military-oriented view in interpretation by maintaining that all States possess the inherent right to defend against foreign aggression in outer space, as well as within earth's atmosphere. ${ }^{94}$ As Professor A. Vlasic notes:

\begin{abstract}
If one chooses to ignore the controversy concerning the "true" meaning of "peaceful" in the Outer Space Treaty, it is safe to conclude that the Treaty permits the deployment in outer space of anti-satellite weapons, directed energy weapons, or any other kind of weapon, as long as these weapons are not in conflict with the prohibitions of Article IV [such as weapons of mass destruction in orbit] of the Outer Space Treaty, or some other international agreement. ${ }^{95}$
\end{abstract}

As militarization of space gained momentum, in the early 1970s, détente slowed down the arms race opening a new window of opportunity for the superpowers which led to the signing of two significant treaties - the Anti-Ballistic Missile Treaty (A.B.M. Treaty) and the first Strategic Arms Limitation Talks (S.A.L.T.) Treaty. Both these treaties tacitly recognize the legality of reconnaissance satellites as a means of verifying treaty compliance, and prohibit any "interference" with their function. ${ }^{96}$ The provisions are no surprise since consensus was that

\footnotetext{
93 Outer Space Treaty, supra note 66, art. 9.

${ }^{94}$ C.Q. Christol, The Modern InTERnAtional LAW OF OUTER SPACE 22, 29 (1982).

${ }^{95}$ Vlasic, Space Law and the Military Applications of Space Technology, supra note 9, 397.

96 See A.B.M. Treaty, supra note 13, at art. XII, II\&2; S.A.L.T. I, supra note 13, at art. V, II\&2.
} 
positive activities in space included, but were not limited to, the use of military satellites to monitor the performance of arms-control agreements. Two primary provisions of the A.B.M. Treaty have a direct bearing on the weaponization of space - articles V and XII.

Article V (1) provides that "[e]ach party undertakes not to develop, test, or deploy ABM systems or components which are sea-based, air-based, space-based, or mobile land-based."97 Though there were no space-based A.B.M. systems in existence in 1972 when the treaty was adopted, the space program of each Party was highly advanced and each could foresee the use of space-based A.B.M. systems. ${ }^{98}$ Article XII is perhaps even more significant to the long-term use of space by military systems beyond the narrower question of A.B.M. systems:

1. For the purpose of providing assurance of compliance with the provisions of this Treaty, each Party shall use national technical means of verification at its disposal in a manner consistent with generally recognized principles of international law.

2. Each Party undertakes not to interfere with the national technical means of verification of the other Party operating in accordance with paragraph 1 of this Article. ${ }^{99}$

Paragraph 1 is significant. Though the legality of military surveillance activity from space was established in international law previous to the A.B.M. Treaty, the treaty gave formal sanction to the practice by the two leading space-faring states. In particular it acknowledged the legality of space-based surveillance via satellite and entrenched this as "an essential component of the international arms control regime."100 Thus, while the term "peaceful" is contained in all U.N. documents devoted to outer space matters, Richard A. Morgan notes that most experts agree that the Outer Space Treaty does not prohibit "military use" of space. ${ }^{101}$ He goes on to note that there is a "consensus, within the United Nations that 'peaceful' more specifically equates to 'non-

\footnotetext{
97 A.B.M. Treaty, supra note 13 , at art. V (1).

${ }^{98}$ G.H. ReYNOLDS \& R.P. MERGES, OUTER SPACE: Problems OF LAW AND POLICY (2nd ed., 1997$) 97$.

${ }^{99}$ A.B.M. Treaty, supra note 13, at art. XII (emphasis added)

${ }^{100}$ REYNOLDS \& MERGES, supra note 98, at 97.

101 Richard A. Morgan, Military Use of Commercial Communication Satellites: A New Look At the Outer Space Treaty and "Peaceful Purposes", 60 J. AIR L. \& COMM. 237, 288 (1994).
} 
aggressive." 102 However the general stance by commentators noted by Morgan is at odds with the Conference on Disarmament's observation in 1986 that "[n]o country should develop, test or deploy space weapons in any form." 103

In sum, despite the use for peaceful purposes centerpiece of the space law regime, key provisions readily lend themselves to interpretations that would support many aspects of militarization and weaponization of space. The matter is thus open and dependent on what perspective a state adopts since it can readily stretch the elastic nature of the space law regime to fit its particular analysis.

The article now turns to juxtapose weaponization of outer space and the U.N. Charter regime on the use of force. The snapshot offered demonstrates the legal and interpretation muddle that confronts the international community with interpretations possible both ways depending on the interpreter demonstrating a lack of clarity or perhaps internal contradictions in the space law regime. As will be seen, just like the space law regime, the application of the U.N. Charter provisions on the use of force create plenty of middle ground when confronted with the weaponization of space.

\section{SPACE AND THE UN CHARTER: PEELING A LEGAL ONION?}

When the U.N. Charter was drafted in 1945, the right of self-defense was the only included exception (reserved to state discretion) to the general prohibition of the use of force. Previously, in addition to self-defense, customary international law had accepted reprisal, retaliation, and retribution as legitimate responses by states whose interests had been injured. Under the U.N. Charter, unilateral acts of force were not characterized as self-defense, regardless

\footnotetext{
${ }^{102} I d$.

103 Conference on Disarmament, Final Record of the Three Hundred and Fiftieth Plenary Meeting, U.N.Doc. CD/PV.350 (1986).
} 
of motive were made illegal. Individual or collective self-defense became the cornerstone relating to use of force and since then has been invoked with regard to almost every use of external military force.

The U.N. Charter, while seeming to present a neat and tidy regime on the use of force, nonetheless reflects the drafters' singular focus on creating a system to govern conventional warfare. The concept of war as then understood specifically covered conventional warfare and was premised on the use of aerial, terrestrial and sea spaces. This fact is reflected strongly and almost exclusively in the existing regime on the law of armed conflict. Few, if any, of the diplomats, politicians and legal experts during the drafting of the U.N. Charter seem to have anticipated that in the next several decades technology would advance to a stage where the militarization and weaponization of space would move from wishful thinking into a possibility and finally a reality.

The pivot on which present day jus ad bellum hinges is article 2(4) of the Charter, which articulates the principle of the prohibition of force in international relations. Article 2(4) avoids term "war." The use of force in international relations proscribed in the article includes war and transcends war to cover forcible measures short of war. Though the U.N. Charter forbids the "threat or use of force against the territorial integrity or political independence of any state, or in any other manner inconsistent with the Purposes of the United Nations," 104 the meaning of this prohibition remains hotly contested.

The reality noted in part II of the article is that despite the space regime being premised on the basic principle of "peaceful" purposes which at first glance seems to militate against any sort of militarization or weaponization operations, ${ }^{105}$ "[o]uter space has achieved the dubious

\footnotetext{
${ }^{104}$ U.N. CHARTER, art. 2(4).

${ }^{105}$ Morgan, supra note 101, at 248.
} 
distinction of being the most heavily militarized environment accessible to humans."106 As a result, there has been tacit, if not explicit, acknowledgment of this reality. When one considers the Outer Space Treaty, the so-called Magna Carta of outer space, article III of the Outer Space Treaty provides perhaps the clearest indication that the international law of war will apply to space warfare.

\begin{abstract}
States Parties to the Treaty shall carry on activities in the exploration and use of outer space, including the moon and other celestial bodies, in accordance with international law, including the Charter of the United Nations, in the interest of maintaining international peace and security and promoting international co-operation and understanding. ${ }^{107}$
\end{abstract}

Ramsey notes "[t]his observation provides the strongest evidence that as far as its principles will apply to future technologies, the law of war has been incorporated into military space operations by virtue of the Outer Space Treaty." 108 However, this bold assertion is not black and white. The same provision equally applies to the counter perspective that space should be a science sanctuary for endeavors geared towards peace not a battleground. This arises from the fact that the article applies the restrictions of international law to outer space activities. Considering that the legal regime on the use of force and the law of war are products of international law, the logical presumption is that it encompasses the pacific theme that lies at the heart of the U.N. Charter. This is especially so in view of the fact that article III makes specific reference to the U.N. Charter. This being so, the argument advanced above regarding the tacit application of the provision to space warfare would not hold much water. However, though the application of international law to outer space is hemmed in by a pacific theme championing the interest of maintaining international peace and security, the elastic space regime affords interpretation one way or the other.

\footnotetext{
${ }^{106}$ Vlasic, The Legal Aspects of Peaceful and Nonpeaceful Uses of Outer Space supra note 7, at 51.

${ }^{107}$ Outer Space Treaty, supra note 66, at art. III (emphasis added).

${ }^{108}$ Ramsey, supra note 71, at 127.
} 
Sliding further into the legal quagmire, let us consider whether a cyber-attack constitutes an "armed attack" justifying self-defense within the framework of article 51. Armed attack clearly implies the use of arms or military force and has an offensive, destructive, and illegal nature. ${ }^{109}$ Significant in this regard is the "Definition of Aggression" adopted by the UN General Assembly through Resolution 3314. ${ }^{110}$ Article 1 defines aggression as the "use of armed force by a State against the sovereignty, territorial integrity or political independence of another State, or in any other manner inconsistent with the Charter of the United Nations, as set out in this Definition." "111 To the extent that "non-peaceful" means the aggressive use of force, such uses are prohibited by the U.N. Charter's provision to the contrary. Thus, A.S.A.T.s and other S.O.V.s with the capability to deploy ordnances from space deviate from the non-aggressive character of satellites, and in so doing may appear to violate the non-aggressive mandate required of all space activities under the "peaceful purposes" restriction.

This is insofar as a cyber-attack on a State's commercial satellites is commensurate with the use of armed force by a State against the sovereignty of another State (or perhaps, more specifically, with the use of weapons by a State against the territory of another State) . . and not justified as either self-defense or collective security. ${ }^{112}$

The crux of the matter, though, is that the Outer Space Treaty does not prohibit the transiting, or even the orbiting, of conventional weaponry in space. As Ramsey notes:

The prohibition on orbiting of weapons of mass destruction, including nuclear weapons, strongly suggests the distinction between those weapons, and conventional weapons of lesser destructive power, including those directed at satellites. Though Article IV (1) could easily be modified to effect the de-weaponization of space, conventional weapons are not proscribed. ${ }^{113}$

\footnotetext{
109 See J.N. Singh, USE OF FORCE UNDER INTERNATIONAL LAW 15 (1984).

110 Definition of Aggression, G.A. Res. 3314, U.N. GAOR, 29th Sess., Supp. No. 31, at 142, U.N. Doc. A/9631 (1975), reprinted in 69 AM. J. INT'L L. 480 (1975) (adopted without a vote at the 2319th plenary meeting, Dec. 14, 1974).

${ }^{111} I d$.

112 Petras, supra note 12 , at 1248.

${ }^{113}$ Ramsey, supra note 71 , at 84.
} 
Professor Ian Brownlie proposes that weapons which do not employ the force of shock waves and heat associated with more orthodox weapons, may nevertheless be assimilated to the use of force on two grounds: "In the first place the agencies concerned are commonly referred to as 'weapons' and forms of 'warfare ... [and] the second consideration [is] the fact that these weapons are employed for the destruction of life and property." 114 Thus, though space weapons were not actively envisaged during the drafting of the U.N. Charter, whether a satellite is struck by an A.S.A.T. weapon or ordnances are deployed by an S.O.V., under Brownlie's formulation this cyber-attack would equate to the use of armed force. ${ }^{115}$

\section{CONCLUSION}

The "peaceful purposes" concept is an accepted axiom of customary international Space Law and continues to be recognized in the majority of space-related international agreements and U.N. declarations or resolutions enacted today. Though the term "peaceful" is encapsulated in virtually all U.N. documents devoted to outer space matters, "[m]ost experts agree, however, that the Outer Space Treaty does not prohibit "military use" of space. In this regard, Richard A. Morgan notes that the "peaceful" purposes centerpiece of space law

does not rule out the military use of outer space or military use of commercial communications satellites. It does not prohibit the use of commercial satellite communications in tactical military operations in which armed force is used. Whether a military use is for "peaceful purposes" cannot be determined by the type of vehicle on which a satellite terminal is mounted, by the vehicle's cargo, by the nature of the communications traffic, or by whether the vehicle or personnel using the equipment are engaged in military operations involving the use of armed force. Satellite earth stations need not be "turned-off" merely because the vehicle on which they are mounted are engaged in an operation involving the use of armed force. ${ }^{116}$

\footnotetext{
${ }^{114}$ IAN BROWNLIE, INTERNATIONAL LAW AND THE USE OF FORCE BY STATES 362 (1963).

${ }^{115}$ Petras, supra note 12, at 1259.

${ }^{116}$ Morgan, supra note 101, at 325.
} 
While there is little controversy that "peaceful purposes" applies to outer space activities controversy comes into play as to what the phrase means. General consensus within the United Nations points to an understanding of "peaceful", as more specifically equating to "nonaggressive". As noted by Qian Jiadong of China during the 1986 Conference on Disarmament: "Outer space should be used exclusively for peaceful purposes for the benefit of ... mankind. No country should develop, test or deploy space weapons in any form. An international agreement on the complete prohibition of space weapons should be concluded through negotiations as soon as possible." ${ }^{117}$ However, controversy arises owing to two divergent views strongly propounded by the two leading space faring nations and thus the vanguard of the development of customary international law on the matter-the U.S. and Soviet Union (now Russia, the rump republic of the former Soviet Union). The original Soviet view was that "peaceful purposes" meant no "military" use of outer space, a view that they later softened ${ }^{118}$ as their military satellite programs came to fruition. ${ }^{119}$ The Soviets have always claimed that their uses of outer space were "peaceful" and "scientific". 120 The U.S. view has always been ${ }^{121}$ that the phrase "peaceful purposes" means "non-aggressive" use of outer space, a view it has adhered to from the beginning of the space age. ${ }^{122}$ Thus, the 1958 U.S. National Aeronautics and Space Act (the statutory basis for the U. S. national space program $)^{123}$ requires that U.S. space activities be devoted to "peaceful purposes",

117 Conference on Disarmament, Final Record of the Three Hundred and Fiftieth Plenary Meeting, U.N.Doc. CD/PV.350 (1986).

${ }^{118}$ Vlasic, The Legal Aspects of Peaceful and Nonpeaceful Uses of Outer Space supra note 7, at 40.

${ }^{119}$ Bridge, supra note 35 , at 658.

${ }^{120}$ Szkalak, supra note 2.

${ }^{121}$ Vlasic, The Legal Aspects of Peaceful and Nonpeaceful Uses of Outer Space supra note 7, at 40.

${ }^{122}$ See Gennady Zhukov and Yuri Kolosov, INTERNATIONAL SPACE LAW 51 (1984).

${ }^{123}$ National Aeronautics and Space Act of 1958, Pub. L. No. 85-568, 72 Stat. 426 (1958) (unamended) (codified as amended at 42 U.S.C. $\$ \$ 2451$ et. Seq. (2000)). 
while also mandating that these activities contribute to "national defense." ${ }^{124}$ It is the national defense limb that brings into play the U.S. view that in as far as weapons are deployed in space for purposes of self-defense, this is permissible. ${ }^{125}$ This stance is at odds with the general sentiment expressed by many states at the 1986 Conference on Disarmament where it was opined that the deployment of space weaponry would only serve to fuel a space arms race as major powers would seek to counter-balance the ability of others to have supremacy in space in the event that such weaponry was used for combat purposes. ${ }^{126}$

Considering that states have an obligation, under both the U.N. Charter and the Outer Space Treaty to use outer space for peaceful purposes, greater emphasis ought to be placed on the "common interests" language contained in Article I of the Outer Space Treaty. The relevant part of the Article provides that Outer Space: "shall be carried out for the benefit and in the interests of all countries,...and shall be the province of all mankind". ${ }^{127}$ An emphasis on the "common interests" would play a prominent role in the re-evaluation and rethinking of the term "peaceful purposes" and resolve the divergent views noted above between the two leading space faring nations through the adoption of a "non-military" definition that will eviscerate the "hedging game" that as prospered and that will inevitably pave the way for a "no-hold barred" approach once space warfare dawns on mankind.

${ }^{124} I d . \S 102$.

125 Richard A. Morgan notes:

"Military use of outer space is fundamental to U.S. national security. Numerous space systems, such as those for navigation, weather forecasting, communications, mapping, geodetic measurement, nuclear explosion detection and monitoring, ballistic missile early warning, photo reconnaissance and surveillance, are considered 'force multipliers' which support and enhance military operations"

Morgan, supra note 101, at 248.

126 Conference on Disarmament, Final Record of the Three Hundred and Fiftieth Plenary Meeting, U.N.Doc. CD/PV.350 (1986).

${ }^{127}$ Outer Space Treaty, supra note 66. 
The basis for a "non-military" definition is further championed by Professor Bin Cheng. He draws a tight, cogent analogy between the "peaceful purpose" clause in the Outer Space Treaty with the identical clause in the Antarctic Treaty of 1959 which it mirrors. ${ }^{128}$ He notes that a synthesis of the Antarctic Treaty brings to light two important points applicable to interpreting the Outer Space Treaty clause: "peaceful" means non-military and references to military installations and maneuvers is not exhaustive but indicative. ${ }^{129}$

About five decades after research into space weaponry commenced, there is no binding international instrument limiting the use of such weapons. This has contributed to states' reluctance to foreclose development of space weapons. With contemporary technological and engineering breakthroughs, it is increasingly evident that a treaty specifically governing means and methods of space warfare is necessary, as the current space law regime presents an unclear and shaky framework. Ramsey notes that an examination of the space law regime discloses that, at a minimum, the following military activities in outer space are not prohibited:

1. The use of military personnel;

2. The use of space-based remote sensors in support of combat or other military purposes;

3. The use of space-based communication, navigation, and meteorological systems for combat or other military purposes;

4. The deployment and non-aggressive use of conventional space weapons; and

5. The transiting of nuclear and other weapons of mass destruction in non-orbital trajectories. ${ }^{130}$

${ }^{128}$ Article I of the Antarctic Treaty provides:

1. Antarctica shall be used for peaceful purposes only. There shall be prohibited, inter alia, any measures of a military nature, such as the establishment of military bases and fortifications, the carrying out of military maneuvers, as well as the testing of any type of weapons.

2. The present Treaty shall not prevent the use of military personnel or equipment for scientific research or any other peaceful purpose.

The Antarctic Treaty, done Dec. 1, 1959, 1 U.S.T. 794, T.I.A.S. No. 4780, 402 U.N.T.S. 71 (effective June 23, 1961).

${ }^{129}$ See Cheng, The Legal Status of Outer Space and Relevant Issues: Delimitation of Outer Space and Definition of Peaceful Use, 11 J. SPACE L. 89, 101 (1983), at 102.

${ }^{130}$ Ramsey, supra note 71 , at 157. 
The space law regime yields little information on space warfare. Though space militarization and weaponization, has been actively pursued for decades: "[The law of armed conflict] is no longer a body of law designed to ensure a fair fight between two opponents..."131 Indeed, it would seem that this is what lies behind the race to space supremacy. One commentator observes that space law, including the Limited Test Ban Treaty, Outer Space Treaty, AntiBallistic Missile Treaty, and the Moon Agreement, was developed to "permit, indeed to endorse, the arms race, including the militarization of space."132 The prospect of space warfare requires the formulation of a new perspective on the U.N. Charter regime on the use of force for two primary reasons. Weaponization of space, which sits uneasily with the "conventional" bias of the U.N. Charter, will lead to ghosts from the Cold War era coming back to life, in particular the "counterforce attack" paradigm. ${ }^{133}$ The problem of destroying ballistic missiles on the ground before they are launched is widely recognized in military circles as far more tractable than the difficult challenge of destroying them in flight after launch. With the United States pursuing its ballistic missile defense shield, it is not impractical to assume that China or Russia will have no choice but opt for military strikes against counter value targets (enemy cities) rather than against counterforce targets (enemy missiles) should there be military conflict. Tucked within this paradigm is the concept of limited deterrence which rests on a war-fighting paradigm aimed at communicating an ability to inflict costly damage on the adversary at every rung on the escalation ladder.

\footnotetext{
131 Michael N. Schmitt, Bellum Americanum: The U.S. View of Twenty-First-Century War and Its Possible Implications for the Law of Armed Conflict, in INTERNATIONAL LAW STUDIES - THE LAW OF ARMED CONFLICT: INTO THE NeXt MillenNium 412 (Michael N. Schmitt \& Leslie C. Green, eds., 1998), reprinted in (1998) 19 Mich. J. INT'L L. 1051.

${ }^{132}$ M.M. Matte, A Treaty for "Star Peace", in 2 Arms ConTrol AND DisARMAMENT IN OUTER Space 190 (N.M. Matte, ed., 1987).

${ }^{133}$ In the Cold War era, developments in non-conventional warfare - the primary non-focus of the U.N. Charter regime led to the articulation of Mutual Assured Destruction (M.A.D.) and the limited deterrence concepts by the superpowers. These concepts were very persuasive in maintaining a balance of sorts.
} 
Along the same spectrum, a broad right of anticipatory self-defense premised on a standard of "emerging or imminent threat" would gain significant currency. This is so especially since some scholars believe that a right of truly anticipatory self-defense has emerged outside of Article 51 in light of the availability of weapons of mass destruction. ${ }^{134}$ Professor Thomas Franck accounts for the emergence of a viable doctrine of anticipatory self-defense through, "the transformation of weaponry to instruments of overwhelming and instant destruction. These [weapons bring] into question the conditionality of Article 51, which limits states' exercise of the right of self-defense to the aftermath of an armed attack. Inevitably, first-strike capabilities begat a doctrine of "anticipatory self-defense." ${ }^{135}$ Professor C. Greenwood weighs in with the observation that in a nuclear age, it is the potentially devastating consequences of prohibiting self-defense unless an armed attack has already occurred that leads one to prefer the interpretation permitting anticipatory self-defense. ${ }^{136}$ The development of such a right is prompted by potential targets seeking to strike first, to use rather than lose their biological, chemical, nuclear and space assets. It is not difficult to envisage that this would introduce dangerous uncertainties relating to the determination of potential threats justifying pre-emptive action once space weaponization matures. With this determination being state-based the probability of opportunistic strikes to cripple another state's military capabilities would be justified as anticipatory self-defense.

In a presentation before the 354th plenary meeting of the Conference on Disarmament, Mr. Dhanapala of Sri Lanka discussed the prevention of an arms race in outer space. He stated: "[W]e must negotiat[e] a treaty or treaties to ban weapons in outer space...If this body confined

\footnotetext{
${ }^{134}$ Derek Bowett, SELF-DEFENSE IN INTERNATIONAL LAW 191-92 (1958).

135 Thomas M. Franck (2001), The Institute for Global Legal Studies Inaugural Colloquium: The UN and the Protection of Human Rights: When if Ever May States Deploy Military Force without Prior Security Council Authorization, 5 WASH. U.J.L. \& POLY'Y 51 57-58.

${ }^{136}$ Christopher Greenwood, International Law and the Pre-Emptive Use of Force: Afghanistan, Al Qaeda,and Iraq, $4 \operatorname{SDLJ} 7,15$ (2003).
} 
itself merely to the examination of issues relevant to disarmament, we would replace the Tower of Babel as the symbol of confused confabulation. Our discussions here must not only be graduated but must also have a sense of direction..."137 In the coming couple of decades, space warfare may well be a reality; this requires the formulation of a new perspective on the law of war. There is need for either an entirely international agreement on the complete prohibition of space weapons or at least the conclusion of a protocol to the outer Space treaty to this effect. ${ }^{138}$ This will eliminate the need for academicians and practitioners to making educated but uncertain guesses based on analogies with other legal regimes. ${ }^{139}$

The need for clear, coherent legal limitations in space is summed up by Colleen D. Sullivan's astute observation that despite the fact that customary law, which has evolved in the last few decades since human-created objects began orbiting the earth and is based on principles designed to keep weapons out of space, the international community must codify them in treaties to assure that weapons remain out of the space environment. ${ }^{140}$ The author concurs enthusiastically with this observation. After all, this has been the general intent of the international community, evidenced by countless statements, numerous declarations and resolutions and the general tenor of the space law regime.

\footnotetext{
${ }^{137}$ Recommended Role for Commercial SATCOM Systems in an Integrated MILSATCOM Architecture, Defense Communications Agency, OSD Review Draft, July 15, 1991, at 2-9.

${ }^{138}$ Conference on Disarmament, Final Record, supra note 117.

${ }^{139}$ Ramsey, supra note 71, at 155.

${ }^{140}$ Sullivan, supra note 35 , at 235.
} 